\title{
The Instrumentality of Indigenous Languages in English Studies in Nigeria
}

${ }^{1 *}$ Acheoah, John Emike, ${ }^{2}$ Hamzah Abdurraheem

${ }^{1 *}$ Department of European Languages, Federal University, Birnin-Kebbi

${ }^{2}$ Department of English, Al-Hikmah University, Ilorin

actualemike@gmail.com

Abstract: This paper examines the mechanisms for exploring Nigeria languages in the teaching and learning of English. The writers do not only recommend the use of Nigerian languages as the medium of instruction in schools, but also dislodge the idea that knowledge of indigenous languages cannot be used to promote the teaching and learning of English in educational institutions. Hinging on Fishman's criteria for language prominence, the paper concludes that so long as there is the concept of positive transfer in language acquisition, areas of convergence and divergence between English and any Nigerian language can be explored in the preparation of classroom materials for effective teaching and learning of English in Nigeria.

Keywords: Sociolinguistics, indigenous languages, English studies, second language, language teaching and learning.

\section{INTRODUCTION}

Although scholars do not agree on the exact number of indigenous languages in Nigeria, the figures are between 200 and 400; see Brann (1990) and Bamgbose (1994) for tips on this. The continued neglect of indigenous languages, (particularly the minority ones) in language planning and policies in multilingual Nigeria is questionable and worrisome. It is unfortunate that instead of promoting the teaching of indigenous languages in Nigeria, Departments of Linguistics in Nigerian universities concentrate on teaching and learning of French and Asian languages without engaging indigenous languages in the pedagogical process. Failed efforts have been recorded in the teaching of English in Nigeria. This unfortunate development is not untraceable to the neglect of mother tongues in English studies. The thrust of this paper is to examine the significance of indigenous languages in the promotion of English studies at all levels of formal education in Nigeria. Salawdeen and Hamzah (2016) advocates for "a multilingual policy, backed by legislation, that would empower other languages, particularly the major-minority languages so that they would be used as media of instruction from pre-primary to primary levels, and as teaching subjects from JSS to SSS levels." In addition, they recommend a Credit pass in one of the major indigenous languages as a basic requirement for admission to tertiary institutions, irrespective of any course of study or discipline. Salawdeen and Hamzah (ibid.) cites that "most countries willing to be detached from the yoke of linguistic imperialism have used the opportunity of independence to assert their authority by declaring an indigenous language as national/official language as we have in the case of Sudan in 1956 which declares Arabic as official language and Tanzania in 1961 with the declaration of Swahili." The dominance of English in important spheres of national life in Nigeria depicts the extent of relegation and redundancy suffered by Nigerian major and minor languages.

\section{THEORETICAL UNDERPINNINGS}

Adeniran, cited in Ayodabo (2013:27-28) presents Fishman's postulations which anchor the integrative, discursive arguments in this paper: "Fishman (1972:18-22) lists four criteria in terms of which language could gain or lose prominence: 
1. Standardization - i.e. the codification of a language in grammars, dictionaries, spellers, style manuals... codification within a community;

2. Vitality - seen in the existence of a living community of its speakers. This is a criterion often applied to distinguish languages that are alive as against some others that are described as dead...;

3. Historicity - as seen in the existence of a group of people who, in addition to their social, political, religious or ethnic ties, also see their language as the bonding medium of their common ancestry...;

4. Autonomy - the subjective feeling (when strongly assertive) by a people that their language is unique i.e. different from some other language whatever contrary scientific view a linguist may hold concerning their speech form..."

\section{INDIGENOUS LANGUAGES AND ENGLISH STUDIES IN NIGERIA}

So far, English studies in Nigeria are not satisfactory. Primary, secondary and tertiary institutions simply relegate Nigerian languages. In primary and secondary schools for example, we are aware of the monotonous drone: "Vernacular speaking is prohibited in the school premises". We acknowledge the fact that indigenous languages can only facilitate English studies if literacy in such indigenous languages is enhanced. Unfortunately, literacy level in mother tongues is embarrassingly low. Nigerians do not show interest in the teaching and learning of native languages. Salawu (2006:2) submits: "For any African that is concerned for the soul and survival of his language, there must be a deliberate and sincere effort to learn and teach the language..." This submission aligns with Wilkins (1975:208) who posits: "... by studying language in as scientific a manner as possible, we should be able to make change in language teaching a matter of cumulative improvement."

For several decades, language attitudes have impacted negatively on Nigerian languages. See Adegbija (2004) for illuminating perspectives on this submission. This paper is a call to action. See Butari (2010), Ayodabo and Acheoah (2013), for perspectives on English studies in multilingual Nigeria. Acheoah (2015a) proposes University of Nigerian Languages (UNLs) for all Nigerian languages. Unlike in the common university system in which students are taught different courses that are related to their disciplines in addition to borrowed courses to make them broad-based and versatile, UNLs is proposed to offer purely indigenous language courses in addition to a few courses from its General Studies Unit. Therefore, it is to consist of two Faculties: the Faculty of Nigerian Languages and the Faculty of General Studies. While the Faculty of Nigeria Languages should accommodate the teaching and learning of several, if not all indigenous languages in Nigeria, the Faculty of General Studies should accommodate courses that are from non-linguistic fields of knowledge: social science, computer science, religious studies, etc. According to Acheoah (2015a), "there is no need to worry over the fact that UNLs "falls short of the benchmark of the National Universities Commission (NUC) for a conventional university. UNLs should be considered as 'emergent specie', proposed to act as a 'task-force' that will put an end to the endless rhetoric over the revival of indigenous languages in Nigeria. It is not to be compared with other universities in Nigeria, although its products should be ranked equally as First Degree graduates and should enjoy same opportunities with university graduates." Although there are initial (tentative) hurdles to bedevil the University of Nigerian Languages, these hurdles will eventually culminate into the rebirth of language nationalism and its attendant advantages (developmental implications) in the country. The wide gap between English and vernacular studies in Nigeria, is too wide for comfort. With UNLs in place, this gap will be made as narrow as possible. If Japan and China could develop with native languages, then closing the gap between English and Nigerian languages in formal education through the efforts of UNLs will not be suicidal. It is commonly claimed that minority languages will be extinct if not promoted. However, contemporary scholars express the view that even major languages in Nigeria can suffer extinction based on some premises; it is a fact therefore, that UNLs are not just going to rescue minority languages from extinction, but also the majority ones. Formal education shows that indigenous languages in Nigeria suffer from different categories of language attitudes. Language attitudes are inimical to language planning. Adegbija $(2004$, p.54) submits: 
Attitudes towards languages are motivated by several factors including their socio-economic value, their status-raising potentials, their perceived instrumental value, their perceive esteem, their perceived functions or roles in the nation, their numerical strength, the perceived political and economic power of its speakers, their use in the official domains, their educational value, etc. Generally, positive attitudes, covert or overt, are developed towards a language that is perceived to have value in all these different areas ... Conversely, negative attitudes, overt or covert, develop towards a language in proportion to its lack of function or narrowing or narrowing of its distribution in registers."

This paper contends that Nigerian languages can only facilitate English studies in the country if literacy level in them is promoted; this implies that their grammar, lexis, phonology, etc. have to be investigated and standardized via extensive research. However, Nigerian languages cannot be developed to facilitate English studies without conscious, sincere efforts on the part of stakeholders.

Phillipson (1992) notes that, "the dominance of English is asserted and maintained by the establishment and continuous reconstitution of structural and cultural inequalities between English and other languages." His position is that English oppresses other languages with its status as a language of modern ideas, science and technology.

\section{Discussion}

It is not impossible for the vocabulary stock of Nigerian languages (major and minor ones) to be enhanced through the research efforts of scholars, particularly tenure lecturers of the University of Nigerian Languages. No doubt, these scholars can investigate the phonology, morphology and lexico-semantics of Nigerian languages towards evolving the Standard Variety of each language. Pre-established arguments have been that such languages do not have the extensive vocabulary to cope with globalization (science and technology). Due to the socio-cultural credentials of Nigerian languages, they are suitable for analytical discourses. Nigerian languages can facilitate English studies by being instrumental to national cohesion; many Nigerians do not show interest in learning Nigerian languages (that are not their mother tongues) informally, not to talk of attaining literacy in them. This trend has created divisive tendencies in the country. It has impinged on national cohesion and has slowed down development. Acheoah (2015a) notes that if the University of Nigerian Languages (UNLs) makes Credit pass in Language of Immediate Community (LIC), a pre-requisite for admission into the University, there will be more interest in learning mother tongues formally, and this will foster national cohesion as many Nigerians will become multilingual. Indeed, there will be those who will want to become Lecturers in UNLs across the Nigerian Federation, and will therefore be interested in literacy in mother tongues. The positive implications of UNLs are multi-dimensional and cannot be discussed elaborately within the scope of this paper. For example, Nigerian languages will become relevant in the certification system (attached to learners' career needs). We do not doubt the ability of UNLs to extend knowledge of the phonology, morphology, grammar, lexes, etc. of Nigerian languages via well-integrated scholarly activities within and outside Nigeria. It is erroneous for Nigerians who speak their mother tongues to say they are literates in such mother tongues when obviously, they cannot write in same. The age-long, tenacious cleavage which Nigerian languages have in oral tradition is believed to be the reason for low literacy in mother tongues. Since indigenous languages are strongly rooted in society, they can facilitate English studies in Nigeria if only adequate and appropriate steps are taken by government, schools and researchers to revive them. Scholars note that although Chinua Achebe's Things Fall Apart was translated into 54 languages across the world, one does not know of any Nigerian language that the novel was translated into. Why can't Nigerian writers become literates in mother tongues, thereby articulating their literary ingenuity in indigenous languages?" There are strong indications that indigenous language can facilitate the study of English literature. For example, Acheoah and Beatrice (2015b) note that speaking Yekhee, involves norms (the conventions or rules of social and speech behaviours). The study shows that among the Yekhees, parts of speech play vital roles when used in diverse forms of communications. For example, verbs of state ('being words' 
rather than 'action words') depict existentialism of phenomena. Various devices enhance persuasive discourse in Yekhee. These devices include morpho-syntactic, semantic, phonological and proverbial features ${ }^{1}$. Yekhee, like other indigenous languages in Nigeria, uses extended language to make discourse vehement. Similes, metaphors and symbolism are dominant in both written and spoken discourse in the language. Pitch contours are used by Yekhees in discourse to create a wide range of fluctuating mood. In burial ceremonies for instance, speakers 'impinge' on the mood of listeners by selecting discrete, fluctuating, pitch levels. In addition, Yekhees use reduplication of consonant phonemes to arrest hearers' attention and for effective communication. It is therefore a wrong assumption that indigenous languages lack the credentials to communicate contemporary themes of this globalized age. We strongly hold the view that if Nigerian languages are promoted in formal education and assigned roles in national life, they will be very supportive to English studies. Acheoah and Beatrice (2015) use the figure below to illustrate the communicative potentials of Yekhee:

Components of Yekhee rhetoric:

- Proverbs;

- Pragma-semantic lexemes;

- Figurative language;

- Morpho-syntactic devices;

- Collocations;

- Cause-effect techniques;

- Supra-segmental features;

- Paraphrases;

- Analogies.

Fig1. Components of Yekhee Retoric

English studies is promoted in non-native regions when the norms and values of the non-natives (their identities) are carefully and productively articulated into English studies by linguists involved in curriculum and instructional materials. Bello, Ahmadu and Bulkarima (2008:4) note that "in the Nigerian experience, most conflicts can be somehow linked to identity or ethnicity, the strong index of which is language." Failure to effectively articulate issues of cultural identity in English studies in Nigeria has remained one of the reasons for poor English studies in the country. Acheoah (2014) notes that failure in Ordinary Level examinations in Nigeria is an indication that formal education does not effectively handle the teaching and learning of English. It is logical to opine that socio-cultural divergence between English and Nigerian languages is contributory to poor English studies in Nigeria. We align with Cofresi and Gorman (2004:101) who submit that "each language, with its associated culture and value system, may place unique constraints on the bilingual person's sense of identity." According to Schlesinger (1991:12-13), "A key contribution from linguistics to the debate over the role of language in development is the argument that language influences cognition and is linked intimately to culture. The idea that language is a formative factor in the culture of its speakers is not new: it came into its own in the work of Enlightenment figures such as Johann Gottfried Herder, who claimed that there was a 'parallelism' between the thoughts of a nation and its language, and that language was the medium through which culture was transmitted."

UNESCO (1953:11) makes an interesting point on the instrumentality of indigenous languages in L2 studies: "An important milestone towards an affirmation of the positive impact of linguistic diversity on development came in 1953 in UNESCO's seminal report... This document recognized that instruction in the mother tongue is, at least at the initial levels of education, the most effective way to educate students. It also outlined the 
array of socio-cultural and economic factors which militated against the use of such languages, and spoke of the need to consider geographical, social, linguistic and educational perspective before embarking upon language planning." In a similar vein, John Walsh posits that "because of importance of education in facilitating a community's socio-economic development... it was highly significant that a major global institution gave its blessing to the presence of vernacular languages as media of instruction in the education system (John Walsh 2006:129)." Several scholars acknowledge the implications of language and culture in language pedagogy. For example, Joshua Fishman (1996:81-82) rightly posits: "Language and cultural identity are linked in three ways: indexically, symbolically and in a part-whole fashion. The symbolic link relates to identity, the sense of belonging to a community; the language stands for, or represents, the community of speaker." Thus, English studies can be promoted in Nigeria, if mother tongues which form the basis of the thinking, mindset, perception and analyticity of Nigerian learners of English are incorporated into the pedagogical process. During classroom communication, learners recognize the meaning of signs, language and other semiotic systems as carriers of culture. Thus, "teaching and assessing intercultural competence includes four Components: Language Learning, Language Awareness, Cultural Awareness and Cultural Experience” Denise Lussier (2009:316)².

It is commonly believed by linguists that the different representations of language activities are essentially known as languages. Therefore, the goal of linguists concerned with exploring indigenous languages to promote English studies in Nigeria is simply to explore areas of convergence and divergence between English and Nigerian languages for the benefit of the Nigerian childhood and adult learners of English. We strongly hold the view that errors of children are partly informed by environmental factors; the socio-cultural 'deposits' of Nigerian speech community impinge on their lexis, phonology and grammar. Levinson (1983) rightly notes that "during the early stages of acquisition, children establish an interaction matrix for language learning, and then slowly learn to utilize linguistic means for promoting interaction. We are thus enabled to distinguish between the functionalist's 'explicans' (interactional structure) and the 'explicandum' (language). A second advantage is that children's 'errors' or incompetences reveal to us what adult competences in verbal interaction must involve ${ }^{3 .}$.

There is no doubt about the fact that literacy in mother tongues can promote English studies in Nigeria. According to Banjo (1972), "there are many people in Nigeria who seem to think that the language problems of the country can be solved overnight by means of a decree. It should therefore be stressed at this point that only a 'gradualist' approach has any chance of success, for what is required is reconciliation between what is ideal, what is practicable what then people want. The ideal can be stated quite simply: it is a situation in which every educated Nigerian is fully literate in his mother tongue, completely at home in the spoken and written forms of the country's official language, and sufficiently proficient in English to be able to read any English-medium newspaper without any difficulty. In addition, opportunities will exist for him to learn one or more other languages if he so desires." Problems associated with promoting the corpora of Nigerian languages can be tackled if sincere and tenacious efforts are made to do so. Bamgbose (1972) opines that "there is hardly any Nigerian language for which there does not exist a word list... The main problem with the existing analysis is that they vary considerably in quality... Another problem is that these descriptions are generally couched in technical language and so are not readily available to those interested in devising orthography for their language." Bamgbose (1972) also makes a very elaborate submission which explains what it takes for indigenous languages in Nigeria to operate as facilitators of English studies:

"Assuming that a language is to be used as a medium of instruction, even in the restricted sense of initial literacy, the basic requirements are:

(i) Linguistic analysis of the phonology (sound system) and the grammar of the language;

(ii) Devising a practical orthography based on the linguistic analysis in (i) above, or reforming an existing orthography; 
(iii) Preparation and testing of primers and readers as well as supplementary reading materials;

(iv) Preparation and introduction of Teacher's Notes and Manuals to guide teachers in the use of Primers, readers and perhaps to explain the principles of the orthography.

Where the language is expected to be used as a medium in the wider sense of teaching other subjects through it, additional requirements include:

i. Preparation of textbooks in the school subjects in the language concerned. This will involve extensive corpus planning or language development, for appropriate vocabulary will have to be developed for terminology in elementary mathematics, science, social studies etc. Some amounts of curriculum development may also be involved;

ii. Encouragement and development of written literature in the language. This could be done through organizing writer's workshops and literacy competitions, and facilitating publication of deserving texts."

It will be difficult to solve the problem of poor teaching and learning of English in Nigeria unless the existential experiences of Nigerian learners - as conveyed by mother tongues are articulated into classroom teaching. Ideas and concepts in indigenous languages can be accommodated by the liberal English lexicon in which many foreign words abound. The quantity of ideas that the lexicon of any language can accommodate is not exhaustive. According to Adeniran, cited in Ayodabo (2013:51-52), “... the lexicon grows in order to accommodate new ideas and concepts, and the structures of the language become more flexible and more manipulatable. But such expansion of the individual's vocabulary and his ability to manipulate structures and operate them flexibly as the situation demands are obviously a function of the individual's innate abilities including, of course, the linguistic ability. Another problem with using experience as an attribute of a language or of a bilingual individual is its indeterminacy. Experience is by nature a continuum; it can therefore hardly be used to define a phenomenon such as bilingualism." The Nigerian learners of English want to see English accommodating their actions (ways of life or culture) as their languages contribute to the expansion of the English lexicon. We align with Trager (1972:532) who posits that "language is culture, culture is state in language; language mediates action, action is described in language. Indigenous languages in Nigeria continue to suffer relegation in formal education partly because of poor language planning. Akindele and Adegbite (2005, p.73) view language planning as "a set of deliberate activities systematically designed to select, organize and develop the language resources for development.

It is easier for learners of alien languages to exhibit positive transfer when their knowledge of mother tongues is enhanced at all levels of linguistic analysis. Through positive transfer, learners of alien languages in Nigerian primary, secondary and tertiary institutions can learn English better. They will also understand concepts thought in other subjects, using English as the medium of instruction; thus, in classroom situations, mother tongues will be used to track lexical equivalents in English and Nigerian languages. Within and outside Nigeria, the activities of UNLs can rebuild the image of Nigerian languages. Till date, sociolinguistic discourses are replete with evidences of how mother tongues are humiliated. It is therefore the duty of the proposed UNLs to organize workshops and evolve publications to change the negative attitudes of many Nigerians towards their mother tongues.

\section{CONCLUSION}

The foregoing discussions point to the fact that indigenous Nigerian languages meet Fishman's criteria for language prominence, and so, are credible candidates for the promotion of English studies in Nigeria: they are traceable to the history of the various ethnic groups, they are potent in diverse communication situations and have the potentials to accommodate standardization. 
Lack of motivation in the study of indigenous languages has reached crisis point. With adequate motivation, the standardization and pedagogy of Nigerian languages can be promoted towards facilitating English studies. Acheoah (2015b) contends that initial hurdles associated with promoting indigenous languages in Nigeria can be surmounted is stakeholders are adequately motivated to accomplish the task. Motivation is "the choices people make as to what experiences or goals they will approach or avoid, and the degree of effort they will exert in that respect" (Keller 1983:389). On the whole, this paper establishes that areas of divergence and convergence between English and Nigerian languages can be explored to teach and learn English better in Nigeria.

\section{RECOMMENDATIONS}

To improve English studies in Nigeria as well as the status of Ngerian languages, the following steps are not negotiable:

i. Mother tongues should be effectively taught and examined at all levels of formal education;

ii. Nigerians must have positive attitudes towards mother tongues;

iii. Nigerian languages should be assigned crucial roles in nation-building;

iv. The corpora of Nigerian languages should be improved via corpus and status planning;

v. There should be genuine and meaningful involvement of linguists and government in language planning activities.

\section{NOTES}

1. The linguistic area covered by "Yekhee" (Afenmai) "is approximately the whole of Etsako and some parts of Owan in the present Edo State of Nigeria. The Afenmai Division in the defunct Western Region of Nigeria, was Auchi, but after the creation of the Mid-Western Region (later named Bendel State) in 1963, Akoko Edo District, which was a part of Afenmai, was made a full-fledged Division, and the remaining two districts, namely Etsako and Ivbiosakon, were made two separate divisions, and the latter changed its name to Owan. The administrative headquarters of Akoko-Edo, Etsako Central, Etsako East, Etsako West, Owan East and Owan West Local Government Areas are at present, Igara, Fugar, Agenebode, Auchi, Afuze and Sabongida-Ora respectively (Oseni 2003).

2. Denise Lussier (2009:326) notes that "despite recent efforts and research the relationship between language, thought and culture seems to have been underestimated. Models of language competence aiming at the development of linguistic, sociolinguistic, discursive or pragmatic competencies are now incomplete."

3. Another fascinating submission is that "a break-away group of sociologists, often known as 'ethno-methodologists' arose in reaction to the arbitrary analysis of data that does not make use of socio-cultural norms. This set of people argue that there is need for a set of techniques that the members of a society themselves utilize to interpret and act within their own social worlds - hence the use of the term 'ethno-methodology' which is the study of ethnic participants' own methods of production and interpretation of social interaction (Levinson 1983:294 \& 295)."

\section{REFERENCES}

Acheoah, J. E. (2014). "Ordinary Level English in Nigeria: On Assessment and Failure”. International Journal of English Language, Literature and Translation Studies, Vol. 1. Issue 2:1-5.

Acheoah, J. E. (2014). "Ordinary Level English in Nigeria: On Assessment and Failure”. International Journal of English Language, Literature and Translation Studies, Vol. 1. Issue 2:1-5. 
The Instrumentality of Indigenous Languages in English Studies in Nigeria

Acheoah, J. E. (2015a). "Sustainable Development in Nigeria: The Candidature of Language of the Immediate Community", a paper presented at the International Conference on the Humanities and the Indigenous Knowledge System (IKS) in Africa and Africa's Diasporas, organized by Faculty of Arts, Lagos State University and African Studies Institute, Georgia, Athens, USA, held at the Lagos State University, Lagos, Nigeria between $20^{\text {th }}$ and $23^{\text {rd }}$ July, 2015.

Acheoah, J. E. \& Beatrice A. (2015). "Fundamentals of Yekhee Rhetoric". Journal of African Affairs, Volume 4, Issue 2, pp. 33-38.

Acheoah, J. E. (2015b). "University of Nigerian Languages (UNL) Prospects and Initial Hurdles”. International Journal of Linguistics, Volume-1, Issue-1:1-6.

Adegbija, E. (2004). "Language Policy and Planning in Nigeria”. Current Issues in Language Planning. 5 (3), p.54.

Akindele, F. \& Adegbite, W. (2005). The Sociology and Politics of English Language in Nigeria: An Introduction. Ile-Ife: OAU Press, p. 73.

Ayodabo, J. O. (2013). Linguistic and Sociolinguistic Situation in Nigeria. Ilorin: Haytee Press, 219.

Ayodabo, J. O. and Acheoah, J. E. (2013). "Nigerian English in a Decolonized State: Prospects and Constraints". International Journal of Arts and Humanities, Volume 2, Issue 2: 48-52.

Ayo, Banjo, Ayo (1972). "On the Goals of Language Education in Nigeria”. In Language in Education 001. National Language Centre, p. 16.

Bamgbose, A. (1972). "Towards an Implementation of Nigeria's Language Policy in Education in Nigeria. 001. National Language Centre, p. 22.

Bamgbose, A. (1994). "Language and Nation-building”. In Samuel O. Asein and Festus 0.

Adesanoye (Eds.) Language and Politics: Essays on Language and Society in Africa. Ibadan, Nigeria: Sam Bookman, pp. 1-13.

Brann, C. M. B. (1990) The Role and Function of Languages in Nigeria Government: Language Policy Issues in Nigeria". Sociolinguistics19, pp. 1-19.

Butari, U. (2010). "The English Language and Literacy as Basic Tools for National Development in Nigeria”. ELTAN.

Bello, B. M. (2008). Ahmadu, H. J. and Bulakarima, S. U. "Harnessing the Potentials of

Language and Culture for Conflict Resolution and Management in Nigeria". Paper presented at the 22nd Conference of the Linguistic Association of Nigeria held at the University of Maiduguri 9-13 November, 2008, p.8.

Cofresi, N. I. \& Gorman, A. A. (2004). “Testing and Assessment Issues in Spanish-English

Bilingual Latinos". Journal of Counseling and Development, Vol. 82: Winter 2004. 99-106.

Denise Lussier (2009). "Theoretical Bases of a Conceptual Framework with Reference to Intercultural Communicative Competence". Journal of Applied Linguistics Vol. 4.3, pp. 309-332.

Fishman, J. A. (1996). “What do you lose when you lose your language?” In G. Cantoni (ed.) Stabilizing Indigenous Languages. Flagstaff: Northern Arizona University, p. 817.

John Walsh (2006). “Language and Socio-economic Development: Towards a Theoretical Framework”. Language Problems and Language Planning, 30:20, pp. 127-148.

American Research Journal of English and Literature

Page 8 
The Instrumentality of Indigenous Languages in English Studies in Nigeria

Keller, J. (1983). "Motivational Design of Instruction". In C. M. Reguleth (Ed.) Instructional Design, Theories and Models (pp. 383-436). Hillsdale, NJ: Lawrence Erlbaum Associates.

Levinson, Stephen (1983). Pragmatics.Cambridge: Cambridge University Press, pp.294-295.

Oseni, Z. I. (2003). Afenmai Proverbs. Auchi: Darun-Nur.

Phillipson, R. (1992). Linguistic Imperialism. Oxford, England: Oxford University Press.

Salawu, A. (2006). "Indigenous Language Media: A Veritable Tool for African Language Learning." Journal of Multicultural Discourses, 1(1) 86-95.

Salaudeen, W. O. \& Hamzah, A. (2016). “The Withering Tongues: Empowering Nigerian

Languages in the Face of Global Challenges." In Olatunde Ayodabo, Upah Nahum \& Ona El-Kanemi Patrick (eds.) Lokoja: Department of English and Literary Studies, Federal University Lokoja, pp. 466-478.

Schlesinger, I. M. (1991). “The Wax and Wave or Whorfian Views”. In: R. L. Cooper and B.

Spolsky (eds.) The Influence of Language and Culture and Thought: Essays in Honour of Joshua A. Fishman's Sixty-Fifth Birthday. Berlin \& New York: Monton de Gruyter, 7-45.

Trager, George L. Benjamin L. (1972). “Whorf 1897-1941”. In International Encyclopedia of the Social Sciences XVI. Reprint Edition, pp. 536-38.

UNESCO (1953). The Use of Vernacular Languages Education. Paris: UNESCO,11.

Wilkins, D. A. (1975). Linguistics in Language Teaching. London: Edward Arnold.

Citation: Acheoah, John Emike, Hamzah Abdurraheem, "The Instrumentality of Indigenous Languages in English Studies in Nigeria" American Research Journal of English and Literature, vol 3, no. 1, 2017, pp. 1-9.

Copyright (c) 2017 Acheoah, John Emike, Hamzah Abdurraheem, This is an open access article distributed under the Creative Commons Attribution License, which permits unrestricted use, distribution, and reproduction in any medium, provided the original work is properly cited. 